\title{
The Evaluation of a Hundred Eleven Adult Patients with Acute Hepatitis
}

\author{
Akut Hepatitli Yüz On Bir Yetișkin Hastanın Değerlendirilmesi
}

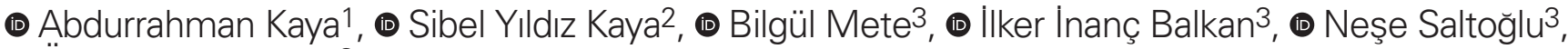 \\ (- Ömer Fehmi Tabak ${ }^{3}$
}

1/stanbul Training and Research Hospital, Clinic of Infectious Disease, Istanbul, Turkey

2Sungurlu State Hospital, Clinic of Infectious Disease, Çorum, Turkey

3/stanbul University-Cerrahpaşa, Cerrahpaşa Faculty of Medicine, Department of Medical Microbiolog, Istanbul, Turkey

\begin{abstract}
Objectives: We aimed to evaluate the etiological, epidemiological and laboratory characteristics of adult patients admitted to our hospital with acute hepatitis.

Materials and Methods: The patients with alanine aminotransferase (ALT) levels exceeding 10-fold and appropriately examined for etiology were included in the study. The markers for hepatothropic viruses and the others, autoimmune markers and hepatobiliary ultrasound were evaluated.

Results: In this study, 111 patients were included, 46 (41\%) were female and $41.4 \%$ of the patients had $\mathrm{AH}-\mathrm{A}, 17.1 \%$ had $\mathrm{AH}-\mathrm{B}, 2.7 \%$ had $\mathrm{AH}-\mathrm{C}$ and $6.3 \%$ were not found any cause. The mean age was $22.11 \pm 6.05$ years in $\mathrm{AH}-\mathrm{A}$. The majority of $\mathrm{AH}-\mathrm{A}$ cases were male with $65 \%$. The mean age was $33.5 \pm 14.78$ in AH-B. There was a statistically significant difference between ages of patients with $\mathrm{AH}-\mathrm{A}$ and $\mathrm{AH}-\mathrm{B}(\mathrm{p}=0.004)$.

Conclusion: Since no specific treatment is available for acute viral hepatitis, preventive measures are more significant. The prevalence of $\mathrm{AH}-\mathrm{A}$ and $\mathrm{AH}-\mathrm{B}$ have declined in the recent years. It is clear that extensive vaccine policies and improved sanitation help eliminate these diseases. In order to ensure complete elimination of viral hepatitis, it is essential to give due importance to the vaccination in childhood as well as in adults.
\end{abstract}

Keywords: Acute hepatitis, virus, transaminase
ÖZ

Amaç: Hastanemize akut hepatit ile başvuran erişkin hastaların etiyolojik, epidemiyolojik ve laboratuvar özelliklerini değerlendirmeyi amaçladık.

Gereç ve Yöntemler: Çalışmaya alanin aminotransferaz (ALT) düzeyleri 10 katın üzerinde olan ve etiyolojisi uygun olarak incelenen hastalar dahil edildi. Hepatothropik virüsler ve diğerleri için belirteçler, otoimmün belirteçler ve hepatobiliyer ultrason değerlendirildi.

Bulgular: Çalışmaya 111 hasta dahil edildi, 46 (\%41) kadın ve hastaların \%41,4'ü AH-A, \%17,1'i AH-B, \%2,7'si AH-C ve \%6,3'ü

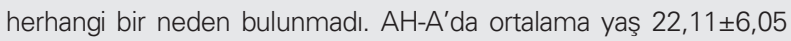
yıldı. AH-A olgularının çoğu \%65 ile erkekti. AH-B'de ortalama yaş $33,5 \pm 14,78$ idi. AH-A ve AH-B'li hastaların yaşları arasında istatistiksel olarak anlamlı fark vardı $(p=0,004)$.

Sonuç: Akut viral hepatit için spesifik bir tedavi mevcut olmadığından, önleyici tedbirler daha önemlidir. AH-A ve $\mathrm{AH}-\mathrm{B}$ prevalansı son yıllarda azalmıştır. Kapsamlı aşı politikalarının ve iyileştirilmiş sanitasyonun bu hastalıkları ortadan kaldırmaya yardımcı olduğu açıktır. Viral hepatitin tamamen ortadan kaldııımasını sağlamak için, aşılamaya yetişkinler kadar çocuklukta da gereken önemi vermek gerekir. Anahtar Kelimeler: Akut hepatit, virüs, transaminaz

Kaya A, Kaya SY, Mete B, İnanç Balkan I, Saltoğlu N, Fehmi Tabak Ö. The Evaluation of a Hundred Eleven Adult Patients with Acute Hepatitis. Viral Hepat J. 2020;26:94-97. 


\section{Introduction}

Acute hepatitis $(\mathrm{AH})$ refers to necro-inflammation of liver which have many causes including viruses, drugs, alcohol, ischemia, autoimmune disorders and other causes. The most common causes of $\mathrm{AH}$ are hepatotropic viruses which have diverse types of transmission and epidemiologies. Hepatitis A virus (HAV), HBV, HCV, HDV and HEV are among most frequently observed in clinical practice (1) 852 patients with acute viral hepatitis from 17 centers were included in this study. Their sociodemographic characteristics, clinical courses, treatments, and laboratory findings were retrospectively analyzed. Results: The most commonly found microorganisms were the hepatitis B virus $155.2 \%$. These are important health problem commonly seen both in our country and in the world. With increasing the administration of the vaccines worldwide, of the etiologies of $\mathrm{AH}$, the prevalence of HAV and HBV has declined in the recent years (2) acute viral hepatitis most frequently is caused by infection with any of three distinct viruses: hepatitis A virus (HAV. Therefore, the epidemiology of $\mathrm{AH}$ has been changed. In this study, we aimed to evaluate the etiological, epidemiological and laboratory characteristics of adult patients admitted to our hospital with $\mathrm{AH}$.

\section{Materials and Methods}

The patients who were followed up in the clinic of the Department of Infectious Diseases and Clinical Microbiology of Cerrahpaşa Medical Faculty between 2001 and 2019 were examined. Patients with alanine aminotransferase (ALT) levels exceeding 10-fold and appropriately examined for etiology were included in the study. The patients were retrospectively analyzed in terms of demographic data, etiology, age, gender, physical examination, laboratory findings, imaging methods and prognosis. Patients with missing diagnostic data were excluded from the study. The markers for hepatothropic viruses [anti-HAV immunoglobulin M (lgM), hepatitis B surface antigen, anti-HBc IgM, anti-HCV, antiHDV, HCV-RNA] and the others [Epstein-Barr virus (EBV), Varicella zoster virus (VZV), Cytomegalovirus, etc], autoimmune markers and hepatobiliary ultrasound were evaluated.

\section{Statistical Analysis}

Data analysis was performed by using the SPSS 20.0 program. The laboratory values of patients were compared with univariate analysis. Subsequently, chi-square test and Mann-Whitney $U$ test were used for categorical variables and continuous variables, respectively. A $p \leq 0.05$ was considered as statistically significant.

\section{Results}

In the study, 111 patients were included, 46 (41\%) were female and 65 (59\%) were male. Forty-six (41.4\%) had AH-A, 19 (17.1\%) had $\mathrm{AH}-\mathrm{B}, 3$ (2.7\%) had $\mathrm{AH}-\mathrm{C}$ and 7 (6.3\%) were not found any cause. The mean age was 34.5 \pm 19.03 (minimum: 16, maximum: 89). In the first admissions to hospital, the mean aspartate aminotransferase (AST) was $1313.54 \pm 1158.46 \mathrm{U} / \mathrm{L}$, the mean ALT was $1672.79 \pm 1132.42 \mathrm{U} / \mathrm{L}$ and the mean serum direct bilirubin was $4.70 \pm 3.76 \mathrm{mg} / \mathrm{dL}$.

The ages ranged from 16 to 39 and the mean age was $22.11 \pm 6.05$ years in $\mathrm{AH}-\mathrm{A}$. The majority of $\mathrm{AH}-\mathrm{A}$ were male with
$65 \%$. The mean AST and ALT levels were 1586.70 \pm 1434.84 and $2096.04 \pm 1165.04$ in $\mathrm{AH}-\mathrm{A}$ respectively.

The ages ranged from 18 to 75 and the mean age was $33.5 \pm 14.78$ in $\mathrm{AH}-\mathrm{B}$. The mean AST and ALT levels were $1474.42 \pm 796.27$ and $2133.95 \pm 1103.90$ in $\mathrm{AH}-\mathrm{B}$ respectively. HDV coinfection did not occur in any case. All AH-B patients developed immunity except 2 patients. Seroconversion occurred in only one of the patients with acute flares of chronic hepatitis B. In acute flares of chronic hepatitis, only one patient developed immunity.

Five patients died from fulminant hepatitis including AH-B (1 patient), acute flares of chronic hepatitis $B$ (1 patient) and unknown causes (3 patients). Toxic hepatitis was caused by ornidazole (1 case), cefazolin (1 case) and polypharmacy (1 case). Hepatic transaminases of all patients returned to normal limits after withdrawal of the drugs.

Hepatic tuberculosis was seen in a patient and the transaminases returned to normal ranges under anti-tuberculosis treatment.

The other etiologies of our patients were autoimmune hepatitis, leptospirosis, ischemic hepatitis, VZV, EBV, tuberculosis, reactive hepatitis and acute cholecystitis (Table 1).

\section{Discussion}

Acute viral hepatitis (AVH) is the most common liver disease in the world. Its prevalence varies according to socioeconomic and geographical characteristics of the countries. $\mathrm{AH}-\mathrm{A}$ is frequently seen in childhood in developing countries (1) 852 patients with acute viral hepatitis from 17 centers were included in this study. Their sociodemographic characteristics, clinical courses, treatments, and laboratory findings were retrospectively analyzed. Results: The most commonly found microorganisms were the hepatitis $B$ virus $55.2 \%$. HBV and HAV are the first two common viruses in many adult $\mathrm{AVH}$ case studies. While some studies have reported type A predominance in $\mathrm{AH}(3,4)$, many studies have shown that

\begin{tabular}{|l|l|l|}
\hline $\begin{array}{l}\text { Table 1. The etiological distribution in patients presenting with acute } \\
\text { hepatitis }\end{array}$ & No. of patients & Percent \\
\hline Etiology of patients & 46 & 41.4 \\
\hline Acute hepatitis A & 19 & 17.1 \\
\hline Acute hepatitis B & 13 & 11.7 \\
\hline $\begin{array}{l}\text { Acute flares of chronic } \\
\text { hepatitis }\end{array}$ & 10 & 9.0 \\
\hline Acute cholecystitis & 7 & 6.3 \\
\hline Unknown & 3 & 2.7 \\
\hline Toxic hepatitis & 3 & 2.7 \\
\hline Acute hepatitis C & 2 & 1.8 \\
\hline Autoimmune hepatitis & 2 & 1.8 \\
\hline Leptospirosis & 2 & 1.8 \\
\hline Ischemic hepatitis & 1 & 0.9 \\
\hline Varicella-zoster virus & 1 & 0.9 \\
\hline Epstein barr virus & 1 & 0.9 \\
\hline Tuberculosis & 1 & 0.9 \\
\hline Reactive hepatitis & 111 & - \\
\hline Total & & \\
\hline & & \\
\hline
\end{tabular}


type B hepatitis is more common $(1,5,6) 852$ patients with acute viral hepatitis from 17 centers were included in this study. Their sociodemographic characteristics, clinical courses, treatments, and laboratory findings were retrospectively analyzed. Results: The most commonly found microorganisms were the hepatitis $B$ virus (55.2\%. For example, in a study, HBV and HAV rates were seen $60.4 \%$ and $27.5 \%$ in $\mathrm{AVH}$ adult patients respectively (6). In our study, $41.4 \%$ of the patients were type A, followed by type B with $17.1 \%$. On the other hand, it was observed that the $\mathrm{AVH}$ cases have markedly declined in the last ten years (Figure 1).

In a study, Eker et al. (7) found that the mean age for $\mathrm{AH}-\mathrm{A}$ and $\mathrm{AH}-\mathrm{B}$ was 21.5 and 33, respectively. In other studies, the mean age was found to be lower in patients with $\mathrm{AH}-\mathrm{A}(8,9)$. In our study, the mean age for $\mathrm{AH}-\mathrm{A}$ and $\mathrm{AH}-\mathrm{B}$ cases are 22.1 and 33.5 respectively. There was a statistically significant difference between ages of patients with type $A$ and with type $B(p=0.004)$.

When the studies in our country examined in terms of gender, Çolpan et al. (9); $42.4 \%$ female, $57.5 \%$ male, Koruk et al. (8); $50 \%$ female and 50\% male, Özkurt et al. (5); $42.7 \%$ female, $57.2 \%$ male were reported. In our study, 46 (41\%) were female and 65 (59\%) were male. While the incidence of $\mathrm{AH}-\mathrm{B}$ did not differ between genders, the majority of $\mathrm{AH}-\mathrm{A}$ cases were male.

In this study, $\mathrm{AH}-\mathrm{A}$ and $\mathrm{AH}-\mathrm{B}$ cases were mostly seen during autumn and winter months (Figure 2) and similar results were

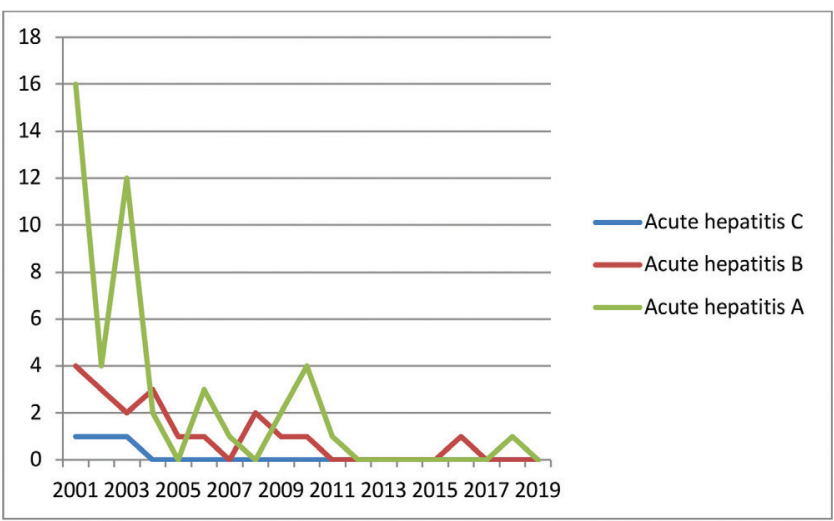

Figure 1. The change of the acute viral hepatitis by years

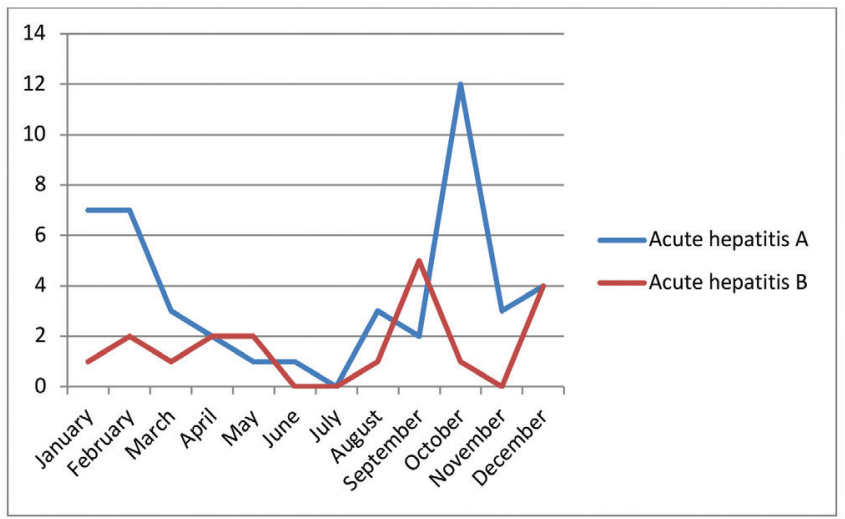

Figure 2. The number of cases of acute viral hepatitis by months found in the previous studies (1,5) 852 patients with acute viral hepatitis from 17 centers were included in this study. Their sociodemographic characteristics, clinical courses, treatments, and laboratory findings were retrospectively analyzed. Results: The most commonly found microorganisms were the hepatitis $B$ virus (55.2\%).

In Turkey, the rate of positive hepatitis $\mathrm{C}$ antibody results is $1.12 \%$ among all groups (10). AH-C has generally subclinic and anicteric presentation and it is often difficult to differentiate acute infection from chronic infection with available tests. In our study, three $(2.7 \%) \mathrm{AH}-\mathrm{C}$ cases were diagnosed with the presence of hepatitis symptoms, more than 10-fold increase in transaminases with anti-HCV and HCV-RNA positivity. Risk factors were not determined in any cases. The prevalence of $\mathrm{AH}-\mathrm{C}$ was found to be high $(2.7 \%)$, compared to other studies conducted in our country $(1,5) 852$ patients with acute viral hepatitis from 17 centers were included in this study. Their sociodemographic characteristics, clinical courses, treatments, and laboratory findings were retrospectively analyzed. Results: The most commonly found microorganisms were the hepatitis B virus (55.2\%).

In the etiology of fulminant hepatitis, the most commonly found infectious agents are HAV in children and HBV in adults (11) gender, etiology, treatment modality, and outcomes. RESULTS A total of 308 patients were analyzed. Hepatitis A (20.9\%). Fulminant hepatitis caused by HBV ranges from $0.1 \%$ to $0.4 \%$ (12). However; the rate was $4.5 \%(5 / 111)$ among all cases. Contrary to previous studies, in our patients, fulminant hepatitis more frequently developed due to unknown etiologies, not in HBV and HAV.

In another study conducted in our clinic between 1989-1991, majority of the patients (55.3\%) were male and the rate of $\mathrm{AH}-\mathrm{A}$, $\mathrm{AH}-\mathrm{B}$ and $\mathrm{AH}-\mathrm{C}$ were $31.2 \%, 63.8 \%$ and $5 \%$ respectively (13). Three patients (2.8\%) developed fulminant hepatitis and all of them died (13). Compared with our study, it was observed that the rate of $\mathrm{AH}-\mathrm{B}$ and $\mathrm{AH}-\mathrm{C}$ decreased over the years

\section{Study Limitations}

This study had some limitations including retrospective design, low number of cases and the lack of clinical symptom and signs. Prospective studies are required to better demonstrate these findings.

\section{Conclusion}

Since no specific treatment is available for $\mathrm{AVH}$, preventive measures are more important to fight these diseases. In our study, though most of $\mathrm{AVH}$ were caused by $\mathrm{HAV}$, followed HBV, the prevalence of $\mathrm{AH}-\mathrm{A}$ and $\mathrm{AH}-\mathrm{B}$ have declined in the recent years. It is clear that extensive vaccine policies and improved sanitation help eliminate these diseases. In order to ensure complete elimination of viral hepatitis, it is essential to give due importance to the vaccination in childhood as well as in adults.

\section{Ethics}

Ethics Committee Approval: Retrospective study.

Informed Consent: Since our study was retrospective, informed consent was not used.

Peer-review: Externally peer-reviewed. 


\section{Authorship Contributions}

Surgical and Medical Practices: A.K., S.Y.K., Concept: Ö.FT., Design: B.M., I.I.B., Data Collection or Processing: A.K., S.Y.K., Analysis or Interpretation: N.S., Ö.F., Literature Search: A.K., Writing: A.K., S.Y.K.

Conflict of Interest: The authors declare that they have no conflict of interest.

Financial Disclosure: There was no aid and sponsor for this study.

\section{References}

1. Karacaer Z, Tosun S, Batrel A, Ahin S, Alta R, Uysal S, Serpil Erol S, Ceran N, Albayrak A, Yıldız IE, Kostakoğlu U, Kaçar F, Kuzhan N, Kadanalı A, Karagöz G, Yenilmez E, Turan DB, Altunçekiç Yıldırım A, Koçak F, Çetinkaya RA, Parlak M, Aydın Ö, Ergen P, Durmuş G, Öztürk Kaygusuz T, Dağlı Ö, Demir C, Yılmaz Karadağ F. Changes in acute viral hepatitis epidemiology in the Turkish adult population: A multicenter study. Turkish J Gastroenterol. 2018;29:177-182.

2. Daniels D, Grytdal S, Wasley A, Centers for Disease Control and Prevention (CDC). Surveillance for acute viral hepatitis - United States, 2007. MMWR. 2009;58:1-27.

3. Parlak E, Özkurt Z, Parlak M. Akut hepatit tanısıyla izlenen olguların değerlendirilmesi. Viral Hepatit Derg. 2012;18.
4. Öncü $S$, Ertugrul MB, Çağatay A, Eraksoy H, Özsüt H, Çalangu S. Eriskin hastalarda akut viral hepatit epidemiyolojisi degisiyor mu? Viral Hepatit Derg. 2002;8:515-517.

5. Özkurt Z, Erol S, Ertek M, Taşyaran MA. Akut viral hepati olgularinin değerlendirilmesi. Viral Hepatit Derg. 2000;9-13.

6. Yöntem B, Hakyemez IN, Aksu A, Simşek F, Kantürk A, Yıldırmak MT. Akut hepatitli 596 erişkin olgunun retrospektif değerlendirilmesi. Viral Hepatit Derg. 2012;18:87-90.

7. Eker A, Tansel Ö, Lu FK, Akata F. Akut viral hepatit a ve b olgularının değerlendirilmesi. Viral Hepatit Derg 2004;10:144-149.

8. Koruk ST, Gürsoy B, Zeyrek FY. Akut viral hepatit olgularının değerlendirilmesi. Viral Hepatit Derg. 2007;22:132-137.

9. Çolpan A, Bodur H, Erbay A, Akinci E. Akut viral hepatit olgularının değerlendirilmesi. Viral Hepatit Derg. 2003;9:20-24.

10. Aydemir Ö, Demiray T, Köroğlu M, Çiftçi IH, Özbek A, Altındiş M. Hepatitis C prevalence in different age groups; people over 50 years of age may receive one-time testing for anti-HCV. Viral Hepatit Derg. 2015;21:40-43.

11. Kayaalp C, Ersan V, Y,lmaz S. Acute liver failure in Turkey: A systematic review. Turk J Gastroenterol. 2014;25:35-40.

12. Hall CB, Wald ER, Martone WJ, Majette SL. Mandell. Principles and Practice of Infectious Diseases. 8th ed. Vol. 1. Philadelphia: Elsevier Saunders; 2015;1815-1839.

13. Dumankar A, Tabak F, Mert A, Aşlamacı M, Aktuğlu Y. Akut viral hepatit olgularının değerlendirilmesi. Cerrahpaşa Tıp Fakültesi Derg. 1993;24:319-326. 